\title{
Dynamic Response Analysis of Lateral Impact Force of Frame Wharf with Rock-Socketed Piles in Inland River Steel Sheath
}

\author{
Xiaolong Zhang, ${ }^{1,2}$ Bingchuan Duan, ${ }^{2}$ Chengzhi Wang $\mathbb{D},{ }^{1}$ and Duoyin Wang $\mathbb{D}^{1,2}$ \\ ${ }^{1}$ National Engineering Research Center for Inland Waterway Regulation, Chongqing Jiaotong University, \\ Chongqing 400074, China \\ ${ }^{2}$ Key Laboratory of Hydraulic and Waterway Engineering of Ministry of Education, Chongqing Jiaotong University, \\ Chongqing 400074, China \\ Correspondence should be addressed to Duoyin Wang; 631502010327@mails.cqjtu.edu.cn
}

Received 19 August 2019; Accepted 14 November 2019; Published 6 December 2019

Academic Editor: Hugo Rodrigues

Copyright (c) 2019 Xiaolong Zhang et al. This is an open access article distributed under the Creative Commons Attribution License, which permits unrestricted use, distribution, and reproduction in any medium, provided the original work is properly cited.

\begin{abstract}
In this study, a three-dimensional finite element model was established to simulate the dynamic response of a large-scale steelreinforced concrete composite high-pile wharf with a rock-socketed steel sheath. The model is based on the second phase of the Chongqing Orchard Harbor structure project in conjunction with the project "Research on the mechanism of interface damage and energy dissipation of the structure of the large-scale steel-reinforced concrete composite high-pile wharf in inland waters." The stiffness of frame wharf is studied from the perspective of modal and transient dynamic analysis of structural dynamics. The distribution of the low-order modal frequency is more uniform. With the increase of the order, the modal frequency of the structure shows a periodical jump. The overall stiffness of the frame structure is larger with the steel sheath, and the longitudinal stiffness is less than the transverse stiffness. Under the action of transverse impact load, the members and joints of the steelconcrete structure exhibit synchronous mechanical response characteristics in the time domain. The peak values of displacement and stress of the structural joints occur $0.05 \mathrm{~s}$ after the peak value of the load-time history, and the peak value of reverse response of force occurs at $2.3 \mathrm{~s}$, which is markedly smaller than the peak value of the response of load direction. Reducing the local positional stiffness of the load point is beneficial to improve the stress of the entire structure. The weak links of the frame structure appear at the joints of the members. Because of the hoop action of the steel sheath, the stress of the reinforced concrete pile core is more uniform. The peak value of the equivalent stress of the steel sheath member is generally larger than that of the reinforced concrete pile core, and the stress is highly concentrated at the joints of the steel tube longitudinal and transverse braces.
\end{abstract}

\section{Introduction}

As a result of the normal operation plan of the Three Gorges Reservoir, which has a maximum water level of $175.00 \mathrm{~m}$, the wharf upstream of the dam in the reservoir area will experience a long period of deep water, as well as a flood period in which the water level will steeply rise and fall. However, the construction period, during which the water level is low, is very short. Furthermore, the geological condition of the reservoir bank at the wharf construction site is bare rock or bedrock covered with a very thin soil layer, which is characterized by large vertical and horizontal fluctuations of bedrock, interlaced sandstone, and mudstone, a large topographic height difference, and a large volume of soil and rock in the port land area. The traditional wharf structure cannot meet many aspects of the demand, including construction and use after completion.

Therefore, the steel shell rock-socketed pile frame wharf has been widely used. To date, some preliminary research results have been obtained on the static load mechanical properties of structures. The steel pipe made of a rib-steel plate was first used in Dazhi Bridge in Japan [1], and the ribs allowed the steel pipe and the reinforced concrete in the pipe to achieve the overall stress effect. The pipe with the rib-steel plate was appraised by the construction center of Japan in 1984. Compared with a concrete-filled steel tube composite 
pile without the rib, it had better economic performance. Using steel tubes to restrain concrete can effectively prevent the development of concrete cracks so that the steel sheeting has higher bearing capacity, better plasticity, and improved toughness compared with the traditional concrete-filled steel tube structure, and it improves the compressive strength and strain capacity of concrete. Largescale tests, elastic-plastic dynamic analysis, and parametric moment and curvature analysis have found that the failure limit state of hyperbolic bending is mainly controlled by the tensile strain of longitudinal reinforcement at the top hinge. When subjected to single curvature bending, the ultimate state is controlled by the tensile strain in the tube at the underground hinge. However, for steel pipes with single curvature and relatively large thickness, the structure may remain elastic during an earthquake $[2,3]$. The bearing capacity of a rock-socketed pile with a steel shell is affected by factors such as the pile diameter, the embedded depth of the pile body, rock mass modulus, the position of the operation point, and the width of flaps. The effect of the steel tube reduces the displacement of the pile top by at least $50 \%$, and the steel tube bears nearly $60 \%$ of the bending moment, while the tube at the maximum point of the antibending moment only bears about $28 \%$ of the bending moment [4-6]. Under the action of lateral load, the large-diameter rock-socketed concrete-filled steel tube pile bears most of the lateral load, so the stress concentration effect near the bottom of the steel tube should be considered in the design. Both the steel tube and backfill sand can effectively limit the displacement of the pile under the action of working load [7]. The use of a wharf structure for the frame structure has received little research attention. To date, comparisons with field load test validation and many changes in the parameters of numerical analysis have revealed that the joint shear force of vertical and horizontal braces with steel liners is bigger and the front row pile structure is larger. At the steel liner and reinforced concrete junction, steel liners form a vertical and horizontal brace connection for a structure with weak links $[8,9]$.

In 1987, aiming to study the dynamic response of structures under impact dynamic loads, Eibl et al. conducted theoretical analysis and experimental research on the structural design of concrete beams and columns that were resistant to accidental impact [10]. In 1992, Louw compared the dynamic response and static characteristics of 28 concrete cantilever columns when they were impacted by lateral loads $[11,12]$. Zhang et al. found that the vibration period of the full vertical pile wharf under the cyclic load is longer than that of the high pile wharf near the shore and closer to the vibration period under the wave load. Under the wave dynamic load, the dynamic amplification of the full vertical pile wharf structure is obvious, and the dynamic amplification system of the displacement of the full vertical pile wharf under the wave cyclic load and the ship impact load number were calculated $[13,14]$. The unstructured frames and pipes at the top of the wharf connect the adjacent sections together, which has an important influence on the dynamic characteristics of the wharf, especially the longitudinal dynamic characteristics [15].
In recent years, many domestic and international scholars have studied the dynamic characteristics of concrete under impact by using numerical simulation and damage theory [16]. At present, there have been many studies on the impact of reinforced concrete. However, because of the relatively late use of the concrete-filled steel tube, which is characterized by beams, columns, and rods, little research on its impact has been carried out, although some qualitative analysis results have indicated the good impact resistance of the concrete-filled steel tube [17]. In 1998, the first study of the lateral impact failure of the hollow steel tube was completed by Dr. Tieguang Zhang in Cambridge University. He tested and theoretically analyzed a variety of elastic impact hollow steel tubes and reported various failure modes of a steel tube under lateral impact. He concluded that steel tubes have good impact resistance [18].

Modal analysis is also a part of structural dynamic analysis. Modal analysis is an important method to determine the stiffness distribution of a wharf structure and learn the stiffness strength of each part of the system. Additionally, it is an important method for the dynamic design and fault diagnosis of a wharf structure [19]. There have been few modal analysis studies on the structure of the domestic wharf. Gu [20] was the first to apply the modal test to wharf structure analysis. In the study, by analyzing the modal test under the three constraints of the large cylinder model, the first three-order mode shapes of the large cylinder wharf structure are obtained, and the modal changes in the wharf structure were analyzed after adding a superstructure. Huang et al. [21] established a spatial model by the finite element method, studied the natural vibration frequency and mode distribution of an overhead vertical wharf structure, and discussed the dynamic characteristics of the wharf structure. Song [22] used the finite element method to establish a simply supported beam-slab model to analyze the modality of the overhead ramp structure of the automobile downhill dock. Structural dynamic characteristics were used to find the dangerous area during structural vibration, which provided a basis for the design of the wharf. Xu [23] aimed to study the shaking phenomenon of a high-pile wharf structure during the operation period. The dynamic finite element numerical analysis method was used to analyze the natural vibration frequency of the wharf structure, and the natural vibration frequencies of the different treatment measures were compared. Finally, the wharf shaking problem was effectively solved. Zhou et al. [24] used the finite element method to establish a finite element model of a pier structure for modal analysis. They obtained the modal characteristics of the pier structure and evaluated its safety by combining the basic working conditions of the pier.

Harmonic response analysis [25] is used to determine the law of the maximum value of the steady-state dynamic response of the linear structure with the load frequency to continuous load changes according to sinusoidal law over time. Spectral analysis is an analytical method that combines the structure of modal analysis with the known spectrum to calculate the maximum dynamic response of the structure. It is mainly used to determine the dynamic response of the structure to random loads or load variation over time. 
Transient dynamic analysis, also known as time history analysis, is used to calculate the dynamic response of a structure under loads (such as sudden load, impact load, and fast-moving load) that change with time. The aim of transient dynamic analysis is to determine displacement, stress, strain, and other changes over time under dynamic load. The relationship between them is shown in Figure 1.

In this study, the Solid65 solid element was used to simulate the pile body between the steel casing and the pile foundation in order to accurately and reasonably reflect the nonlinear contact between the steel casing and the reinforced concrete pile foundation when the steel casing is involved in the pile body force. The contact situation was selected by using the Targe 170 target unit and the Conta173 contact unit to form a contact pair. Modal analysis and transient dynamic analysis are proposed for analyzing the steel-filled rock-socketed pile frame wharf.

\section{Numerical Modeling}

2.1. Engineering Structure Overview. A structural section of the second phase of Chongqing Orchard Port was used as the prototype. The structural section includes five rows of shelves, each of which is three-span four-pile. The span and spacing are $0.8 \mathrm{~m}$, the diameter of the front steel cylinder is $2.2 \mathrm{~m}$, and the diameter of the rear three rows of the steel cylinder is $2 \mathrm{~m}$. The frame structure is shown in Figure 2. The longitudinal and transverse braces of the lower part of the frame structure are hollow steel tubes, the longitudinal and transverse braces of the upper structure are reinforced concrete beams, and the upper part of the steel barrel is connected with the longitudinal and transverse bracing joints of the reinforced concrete. The upper part of the frame structure is the longitudinal and transverse beams of the wharf, and the upper part of the beam is the two-way slab.

\subsection{Numerical Model}

2.2.1. Unit Selection. According to the characteristics of the overhead vertical wharf structure with steel casing in the pile body, six types of units were selected for numerical simulation, namely, Beam188 unit, Solid65 unit, Shell63 unit, Shell1 181 unit, Tar170 unit, and Conta173 unit. The Beam188 unit-a three-dimensional linear finite strain beam element-was used to simulate the beam, track beam, column, transverse contact beam, and longitudinal contact beam in the frame pier structure. The Solid65 solid element was used to simulate the pile body and the contact between the steel casing and the pile foundation in order to realistically and reasonably reflect the nonlinear contact between the steel casing and the reinforced concrete pile foundation when the steel casing is involved in the pile body force. In this case, the Targe 170 target unit and the Conta173 contact unit were used to form a contact pair for simulation, and the Shell63 shell unit was used to simulate the panel. In addition, all the steel members in the structure, such as the steel casing, steel cross bracing, steel longitudinal bracing, steel front bracing, and steel shipbuilding members, were simulated by the Shell181 shell unit. The finite element calculation model used

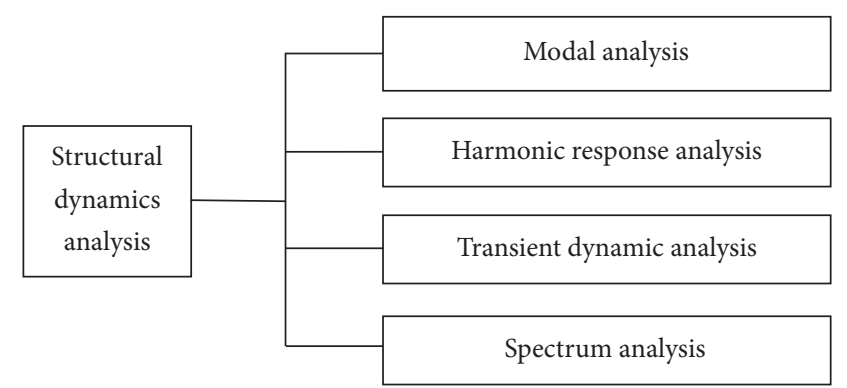

Figure 1: Classification of structural dynamic analysis.

in this study has a large scale, with 445,768 units and a total of 379,841 nodes. The finite element calculation model is shown in Figure 3.

2.2.2. Material Parameter Selection. In the finite element analysis of the reinforced concrete pile base in the wharf structure, reinforced concrete is composed of two completely different materials. If the characteristics of the two are taken into account separately, the modeling is more complex, which substantially increases the freedom of structural displacement and is not conducive to solving the problem. Generally, when we carry out structural analysis, we equate reinforced concrete to homogeneous materials by using equivalent material characteristics, such as elastic modulus and weight. The material parameters set by finite element analysis in this chapter are shown in Table 1.

\subsubsection{Determination of Boundary Conditions and Impact}

Loads. In the numerical model, the embedded point of pile foundation is set as consolidation, and the consolidation position is at the bottom of pile, where the displacement in all directions is zero.

This paper focuses on the structural dynamic response of the terminal structure: it considers the steel guard effect under the dynamic effect of a simulated ship impact force, so it does not consider load effects such as load and cable ingress on the dynamic characteristics of the terminal structure; it only examines the dynamic response of the terminal itself. The load encompasses only the impact load that the structure bears under self-weight and the impact load change curve over time: that is, the impact force-load time curve is related to the performance curve of the guard and the stiffness of the structure itself, and it needs to be determined by appropriate tests. The dynamic load chosen in this study is a simplified half-sine pulse load with a load duration of $2 \mathrm{~s}$, and its peak value was determined from the peak value of the sine wave load in the experiment. The impact force should be determined according to the ship's effective impact energy, the performance curve of the rubber fender, and the stiffness of the berthing member. The impact force acts on two fenders in the prototype structure; given a single fender reaction force of $516 \mathrm{kN}$, the ship's impact force is $1032 \mathrm{kN}$. In a dock structure test, the reverse force of the wharf structure was $10.32 \mathrm{kN}$ using a similar ratio. The impact load is shown in Figure 4. 


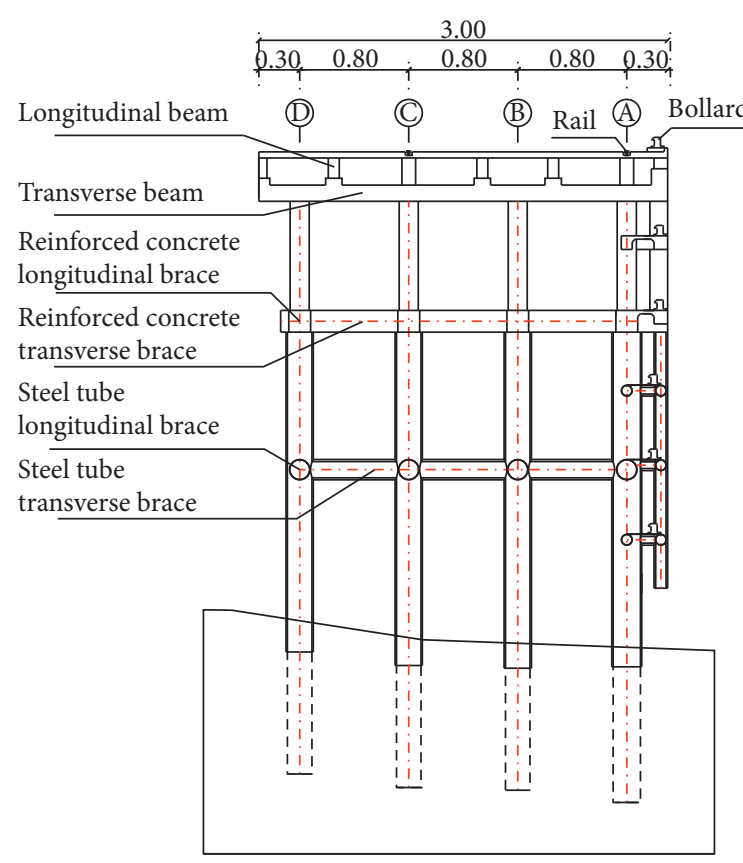

(a)

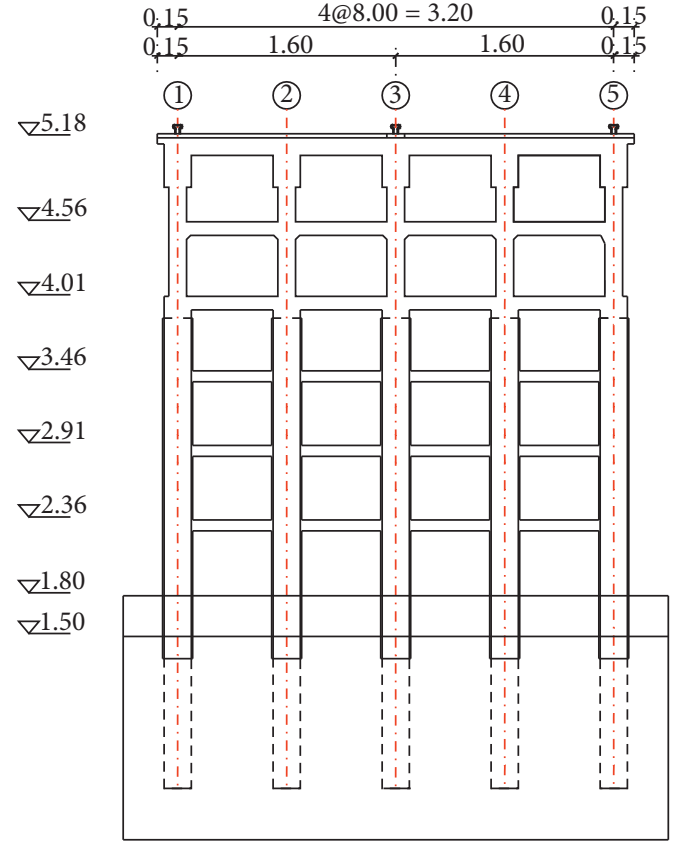

(b)

FIGURE 2: Experimental model (unit: m). (a) Section. (b) Elevation.

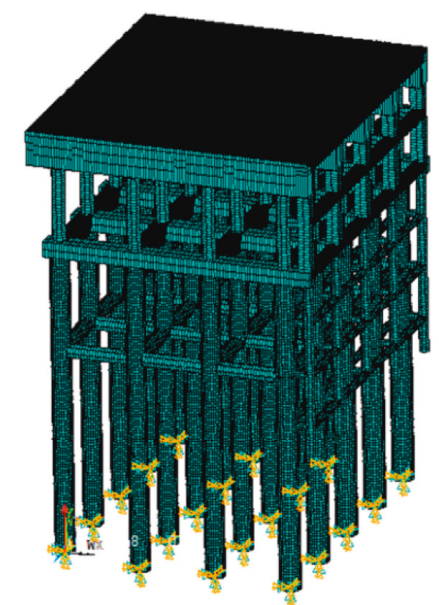

Figure 3: Finite element model of the steel shell cast-in-place pile with a rock-embedded structure.

TABLE 1: Steel casing and concrete material parameters.

\begin{tabular}{lcccc}
\hline Materials & Elastic modulus $(\mathrm{MPa})$ & Poisson's ratio & Density $\left(\mathrm{kg} \cdot \mathrm{m}^{-3}\right)$ & Minimum yield stress $(\mathrm{MPa})$ \\
\hline Steel & $2.1 \times 10^{5}$ & 0.3 & 7800.0 & 418 \\
Concrete & $2.4 \times 10^{4}$ & 0.2 & 2200 & \\
\hline
\end{tabular}

2.2.4. Contact Parameter Setting between Steel Casing and Pile Foundation. The contact relationship between steel pile casing and reinforced concrete pile core of pile foundation includes normal relationship and tangent relationship.

(1) Normal Relation. In the normal relationship, the transmission of contact force should be satisfied, and there is no penetration between the two contact surfaces. For the
Conta173 contact unit selected in the calculation model in this paper, the contact stiffness is defined by the real constant FKN, which is set to 0.1 . The steel casing and the pile foundation are defined as hard contact, and no penetration occurs between the two contact surfaces to reflect the limitation of the lateral compression stress of the steel casing on the reinforced concrete pile under the dynamic load. 


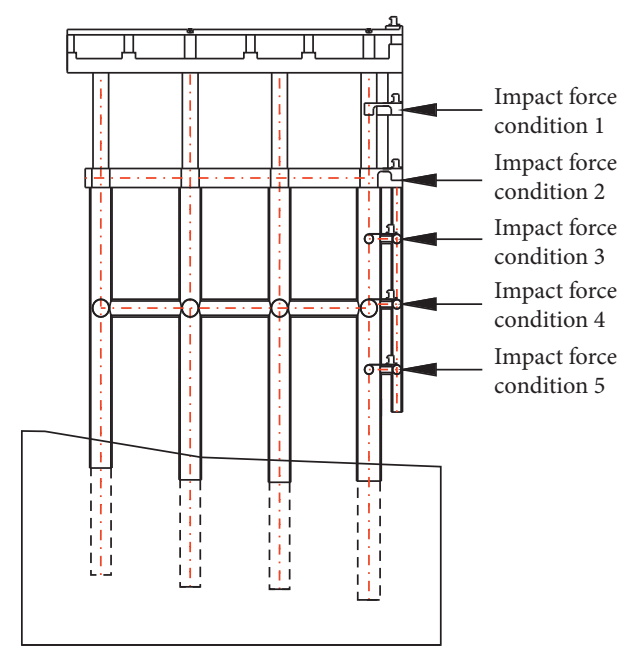

(a)

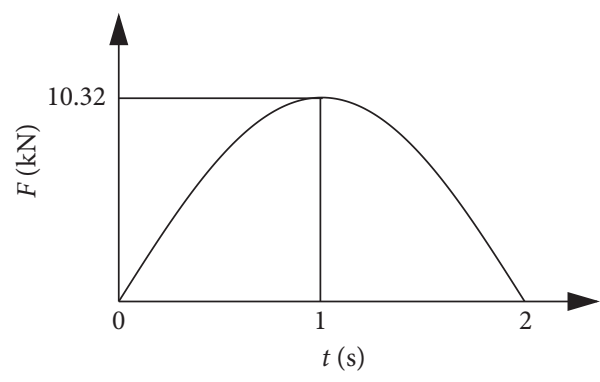

(b)

FIGURE 4: Impact load. (a) Impact force calculation conditions. (b) Semisinusoidal impact load-time history curve.

(2) Tangential Relation. In the tangential relationship between the steel casing and reinforced concrete piles-assuming that there is only a relative sliding trend between the steel casing and reinforced concrete pile foundation under external loads, but no relative sliding occurs-the static friction coefficient between the two contact surfaces is defined as 0.25 [26], which reflects the axial friction effect of the steel casing on reinforced concrete piles under dynamic load.

2.2.5. Load Conditions. Comparison of the results of the dynamic response test of the wharf structure was facilitated by applying the impact force to the P1 framed bend of the whole structure under five conditions corresponding to the dynamic response test (Figure 4).

2.3. Experimental Verification. A structural section of the second phase of Chongqing Orchard Port was used as a prototype, and a physical model with a geometric scale of 1 : 10 was produced. See Figure 5 for details.

The position and number of strain gauges for each section of the member are shown in Figure 6.

In working conditions 3 and 5, the transient strains at two points above the steel sheath were collected, and the experimental data and numerical calculation data were compared. See Figures 7 and 8 for details. The results show that the numerical model can better reflect the dynamic response of the structure under lateral impact load.

\section{Numerical Analysis}

3.1. Computational Model Analysis of the Overhead Vertical Wharf with Rock-Socketed Cast-In-Place Piles with a Steel Retaining Barrel. In the actual calculation, it is important to consider the modes that contribute to the satisfaction of the actual project needs, thereby considerably reducing the workload required to solve the problem. Therefore, the

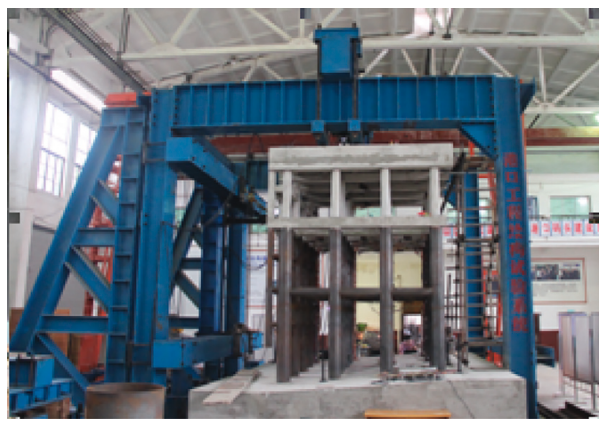

FIgure 5: Physical test model.

natural frequencies and natural periods corresponding to the first 30 modes of the experimental model structure of the orchard wharf were analyzed by using finite element software and are listed in Table 2. Figure 9 shows the frequencymodal order curve of the model structure, which is drawn with the data obtained from the modal analysis.

(1) The frequencies from the first to the third order of the structure are $11.889-13.764 \mathrm{~Hz}$, and the corresponding modes of the first and third orders of the structure are of horizontal motion in the plane without vertical motion. The natural frequencies of the wharf model structure first appear in the region of lower stiffness. The transverse members (such as the cross beam, reinforced concrete cross brace, and steel cross brace) in the structure give the framed bend better integrity and greater stiffness. Longitudinal members (such as longitudinal beams, reinforced concrete longitudinal braces, and steel longitudinal braces) provide weaker stiffness than transverse members. Therefore, the transverse stiffness of the structure is larger than the longitudinal stiffness. From the first mode of vibration, the stiffness of the longitudinal component should be strengthened in the design. 


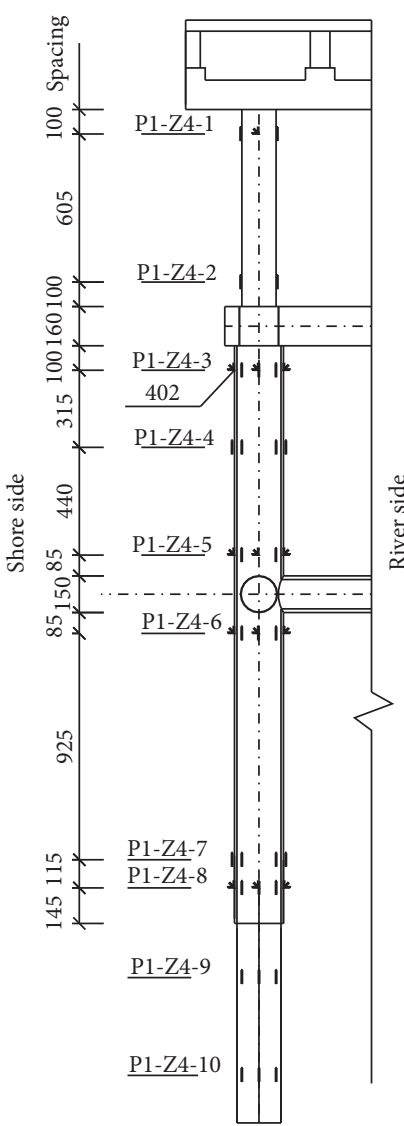

(a)

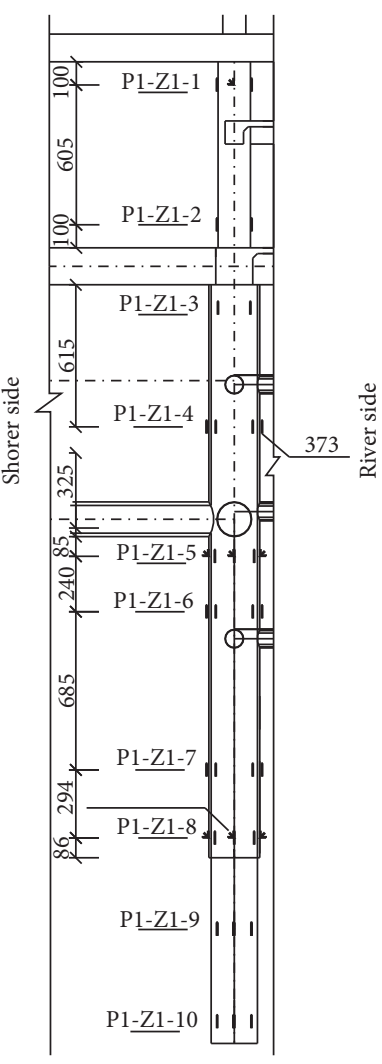

(b)

Figure 6: The position and number of strain gauges for each section of the member. (a) Pile Z4. (b) Pile Z1.

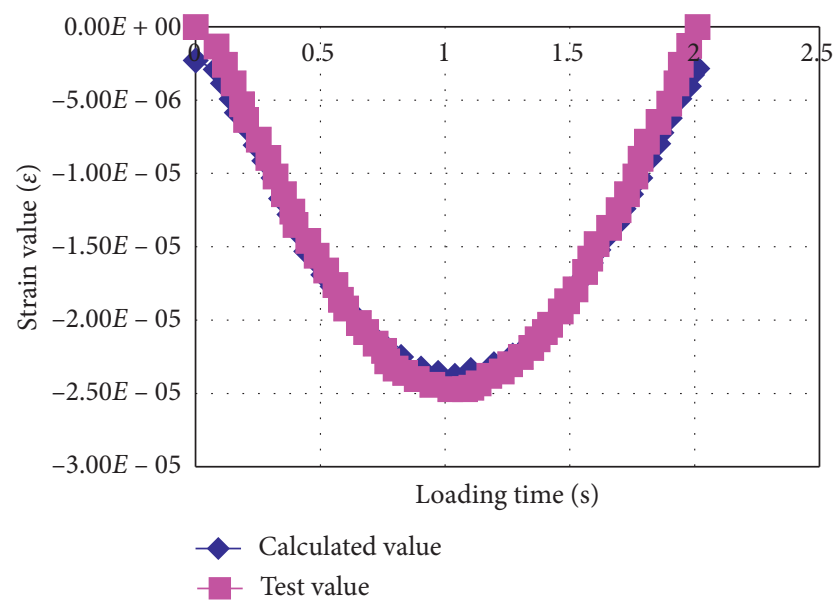

(a)

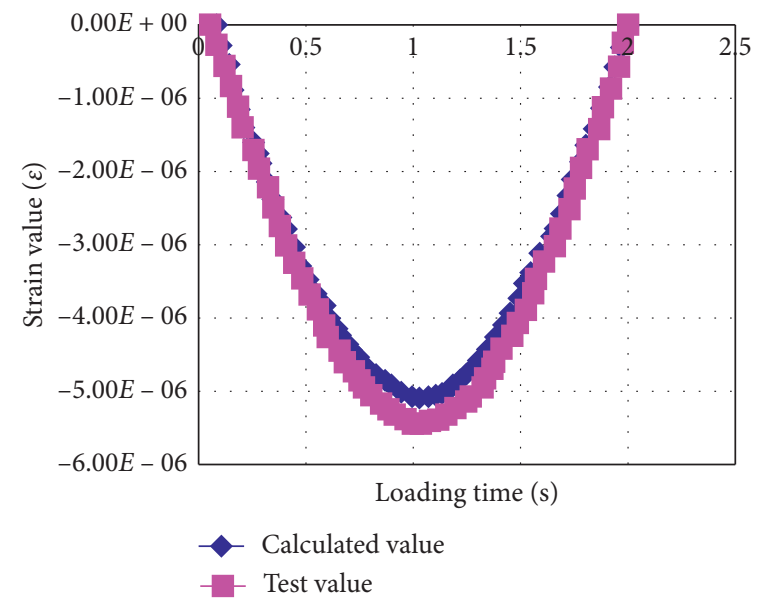

(b)

FIGURE 7: Strain-time history curve of the no. 373 measuring point on the river side of Z1GH. (a) Working condition 3. (b) Working condition 5 .

(2) As shown in Table 2, the natural frequency of the wharf model structure presents a piecewise centralized distribution, and the first three natural frequencies of the structure do not change much in the frequency range of $11-13 \mathrm{~Hz}$, which indicates that the stiffness of the structure is relatively uniform. In the first three modes with low frequencies, the structure is more easily excited by external loads. When the structure is subjected to horizontal loads, such as impact force, the vibration response of the first three modes may predominate. The frequencies of the third and fourth modes, the 


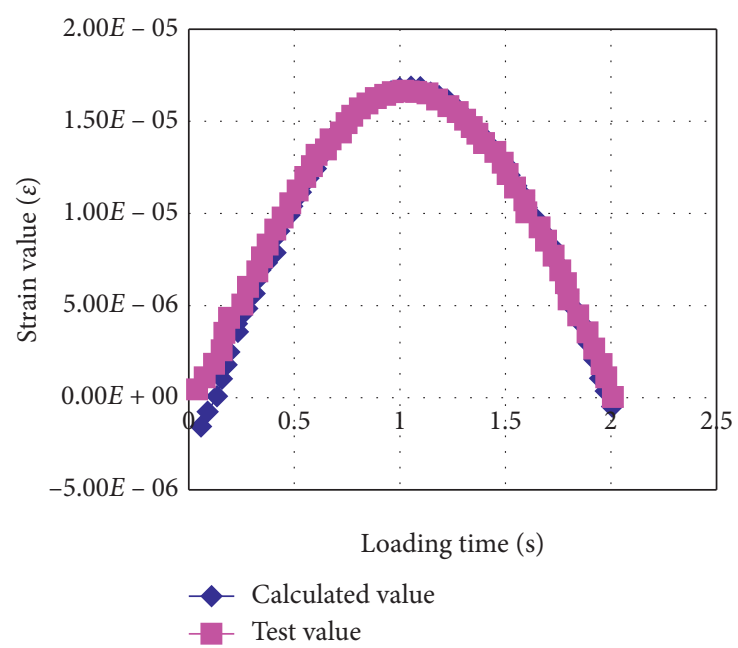

(a)

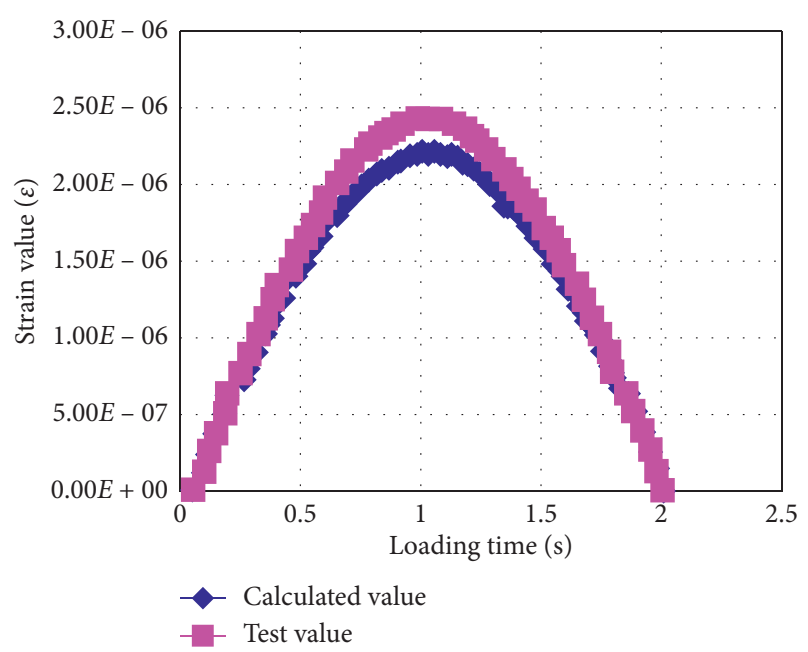

(b)

FIGURE 8: Strain-time history curve of the no. 402 measuring point on the shore side of Z4GHT. (a) Working condition 3. (b) Working condition 5 .

TABLE 2: Frequency and period of each order mode.

\begin{tabular}{|c|c|c|c|c|c|}
\hline Order number & Period (s) & Frequency $(\mathrm{Hz})$ & Order number & Period (s) & Frequency $(\mathrm{Hz})$ \\
\hline 1 & 0.0841 & 11.889 & 16 & 0.0095 & 105.25 \\
\hline 2 & 0.0832 & 12.026 & 17 & 0.0088 & 113.71 \\
\hline 3 & 0.0727 & 13.764 & 18 & 0.0080 & 125.19 \\
\hline 4 & 0.0234 & 42.794 & 19 & 0.0079 & 126.44 \\
\hline 5 & 0.0218 & 45.921 & 20 & 0.0077 & 130.6 \\
\hline 6 & 0.0195 & 51.25 & 21 & 0.0075 & 133.06 \\
\hline 7 & 0.0173 & 57.89 & 22 & 0.0075 & 133.85 \\
\hline 8 & 0.0142 & 70.406 & 23 & 0.0075 & 134.0 \\
\hline 9 & 0.0122 & 82.049 & 24 & 0.0074 & 134.88 \\
\hline 10 & 0.0109 & 91.53 & 25 & 0.0073 & 136.74 \\
\hline 11 & 0.0107 & 93.662 & 26 & 0.0072 & 139.34 \\
\hline 12 & 0.0104 & 95.723 & 27 & 0.0072 & 139.48 \\
\hline 13 & 0.0100 & 99.779 & 28 & 0.0071 & 141.07 \\
\hline 14 & 0.0098 & 101.95 & 29 & 0.0071 & 141.13 \\
\hline 15 & 0.0096 & 104.3 & 30 & 0.0070 & 141.94 \\
\hline
\end{tabular}

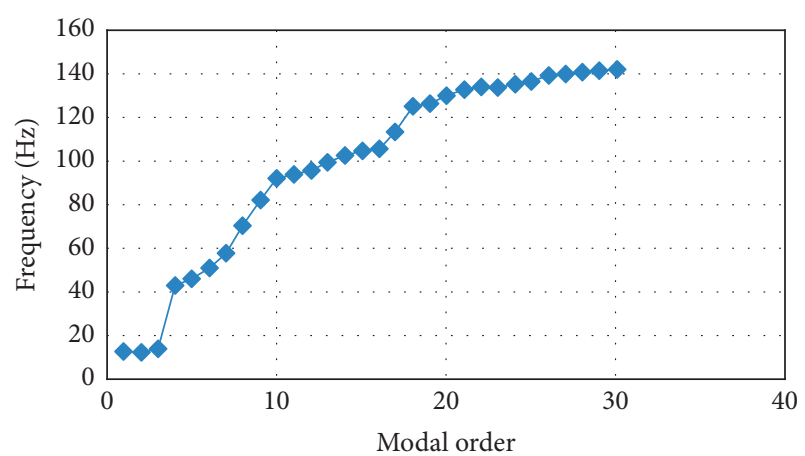

FIGURE 9: Frequency-modal order relationship curve.

seventh and eighth modes, and the tenth and fifteenth modes are close to each other, and the frequencies jump in stages, reflecting the dramatic change in the corresponding stiffness from simple modes to complex modes. Therefore, the excitation sources in these ranges should be avoided as much as possible when the wharf structure test is carried out.

\subsection{Transient Dynamic Analysis of the Wharf Test Model Structure}

3.2.1. Deformation of Structure. The semisinusoidal wave load used to simulate the impact force was applied to the structure, and the displacement response of the wharf structure under this load was calculated. In the finite element calculation of the wharf, the displacement of the wharf top node is the focus of scientific research and engineering design. The peak displacement of the structure's top node and the impacted node under five working conditions are shown in Table 3. The displacement-time histories and structural deformation diagrams of key points under five working conditions are given. Among the data shown, the structural deformation diagram corresponds to the time at 


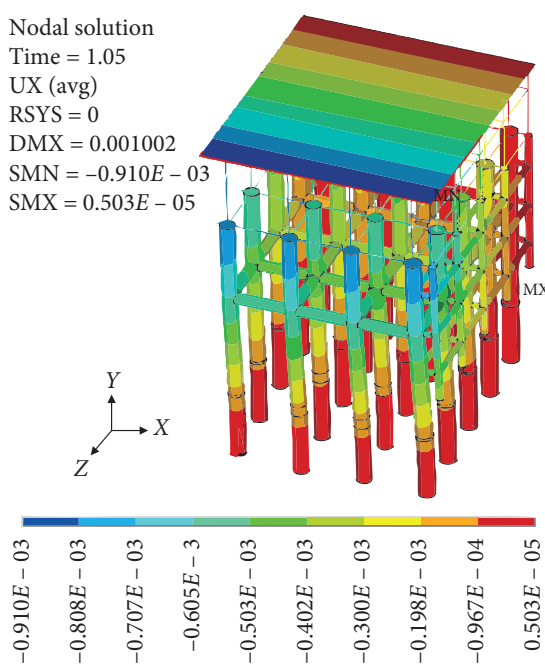

(a)

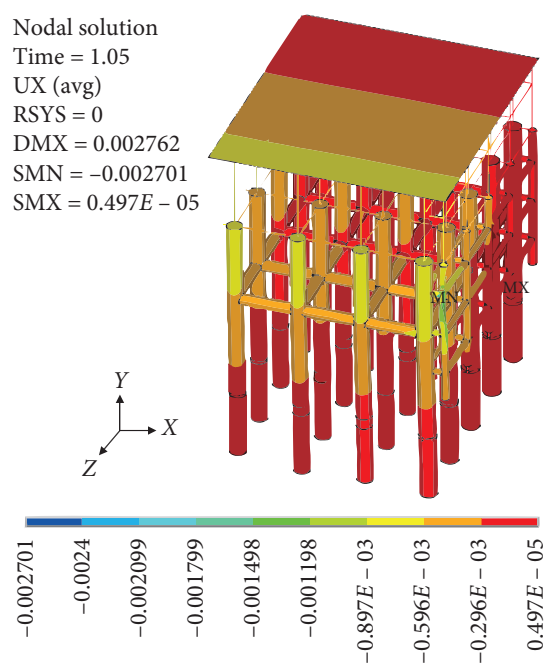

(c)

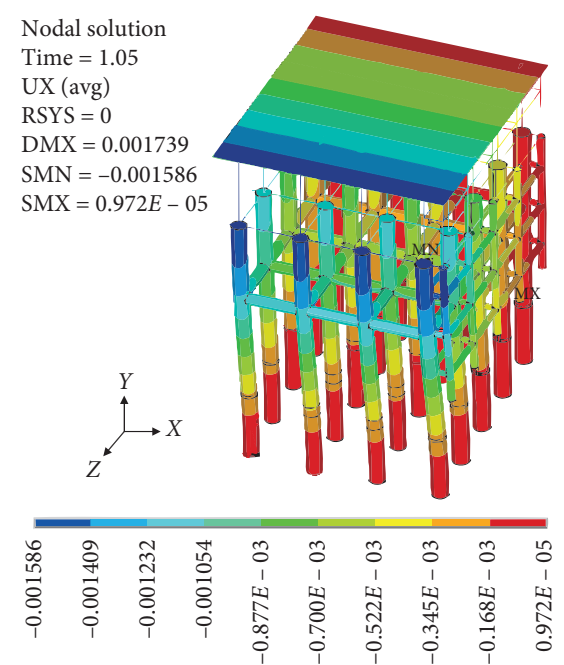

(b)

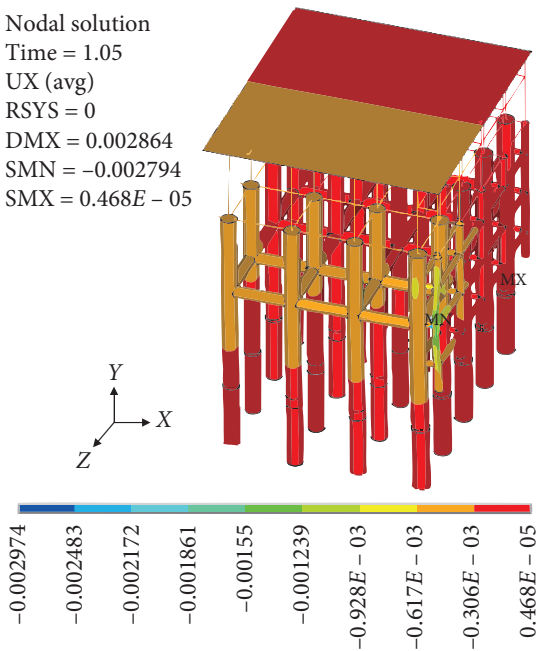

(d)

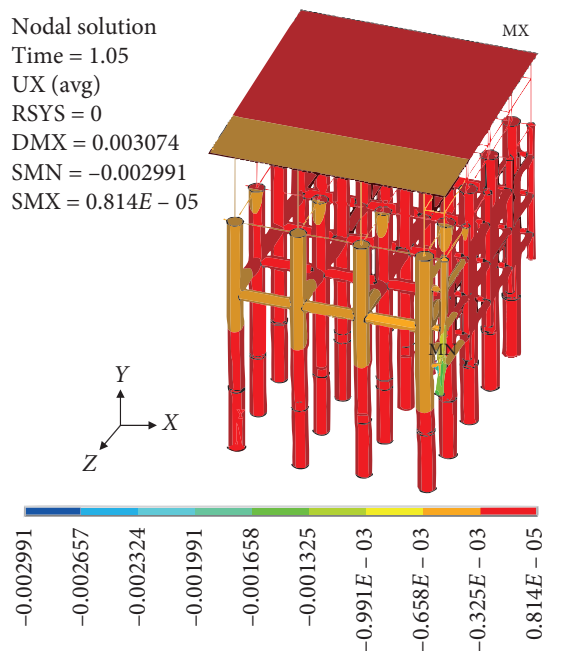

(e)

FIGURE 10: $X$-directional displacement nephogram of structural integral (unit: $\mathrm{m}$ ). (a) Working condition 1. (b) Working condition 2. (c) Working condition 3. (d) Working condition 4. (e) Working condition 5. 


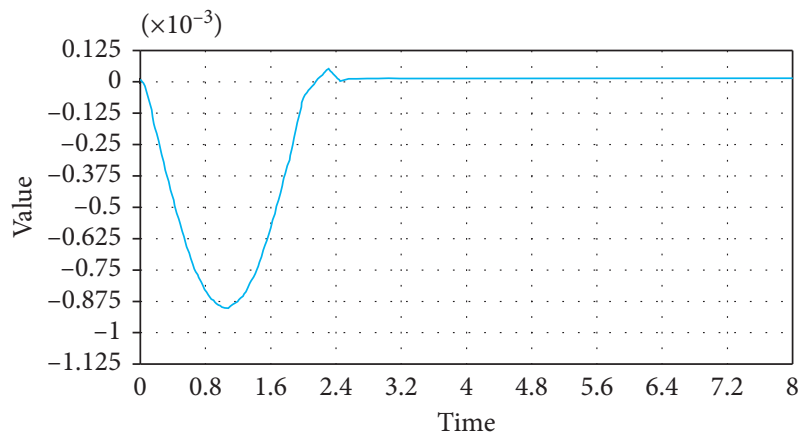

(a)

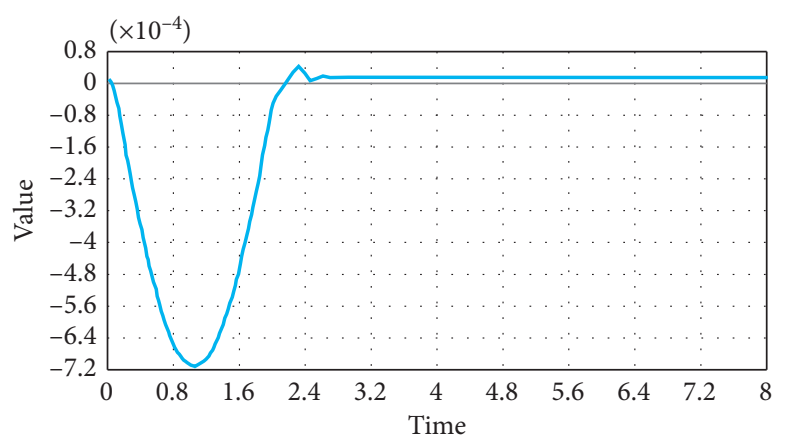

(c)

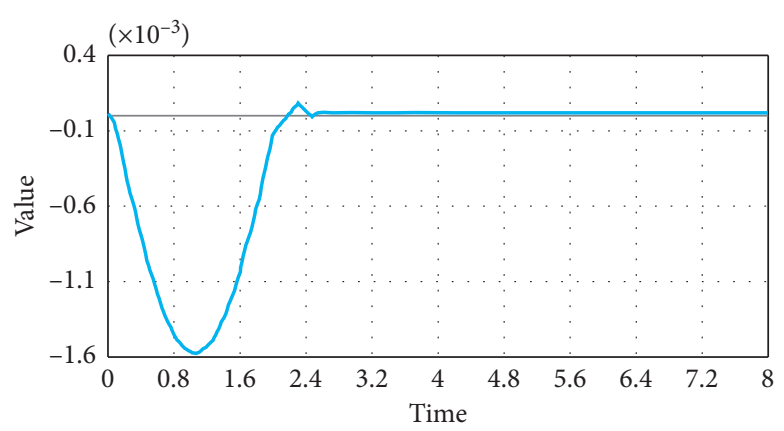

(b)

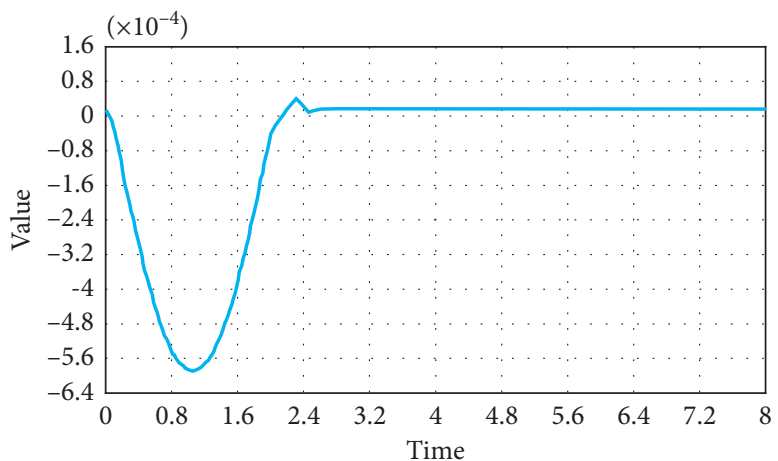

(d)

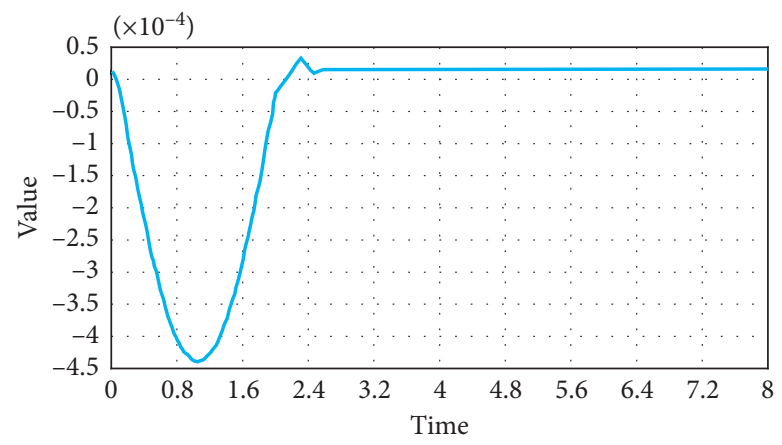

(e)

Figure 11: $X$-directional displacement-time history curves of the top joints of structures (unit: $\mathrm{m}$ ). (a) Working condition 1. (b) Working condition 2. (c) Working condition 3. (d) Working condition 4. (e) Working condition 5.

which the maximum response of the structure occurs under each working condition, DMX is the maximum sum of displacement vectors in all directions in the structural deformation diagram, and SMN and SMX are the minimum displacement and maximum displacement of the nodes corresponding to the maximum response time of the current query, respectively.

The expanded analysis of the whole deformation of the structure and the displacement-time history curve of the joints are detailed below:

(1) The analysis in Figure 10 shows that when the structure fully responds to the impact load, the point with larger vector displacement appears far from the action point, indicating that the structure shows greater overall stiffness under the impact dynamic load. The time at which the maximum impact force reaches $10.3 \mathrm{kN}$ is $1.0 \mathrm{~s}$, but the maximum displacement occurs at more than $1.05 \mathrm{~s}$. This is because the energy transfer of the impact force takes a certain amount of time in the structure, and the response of the structure has a lag effect. The one-way full response lag time of the structure is $0.05 \mathrm{~s}$, which also shows that the frame structure has better overall rigidity.

(2) Table 3 shows that the maximum displacement of the top node of the structure under working condition 2 is the largest and that the displacement of the loading point under working conditions 3-5 is the largest and tends to decrease. This is because, under working condition 2, the lateral stiffness of the structure at the loading point is larger and the local deformation and energy absorption of the loading point are less. 


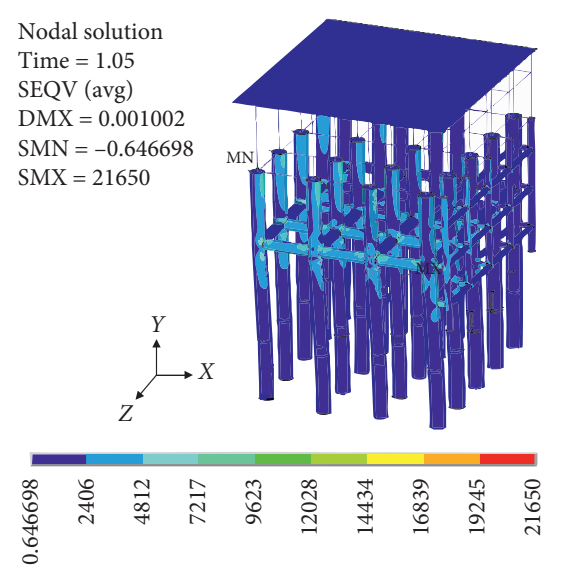

(a)
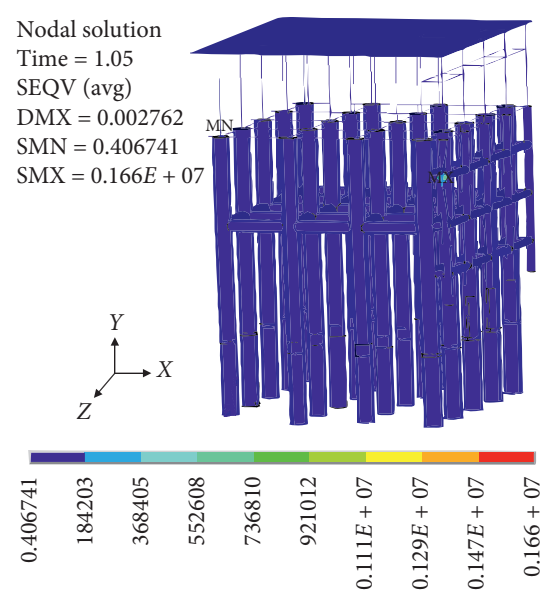

(c)

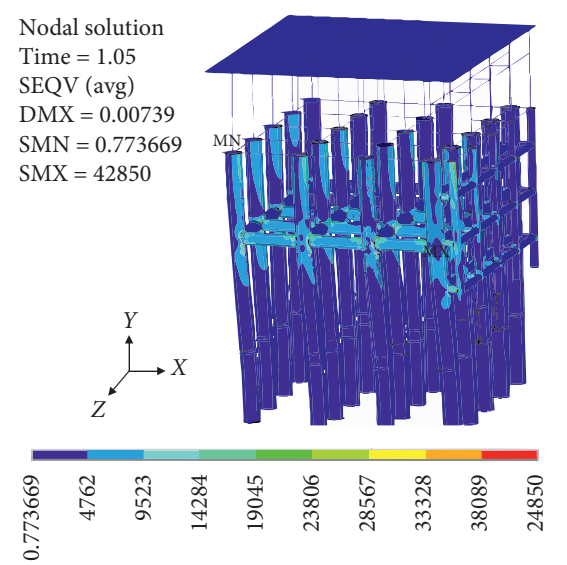

(b)

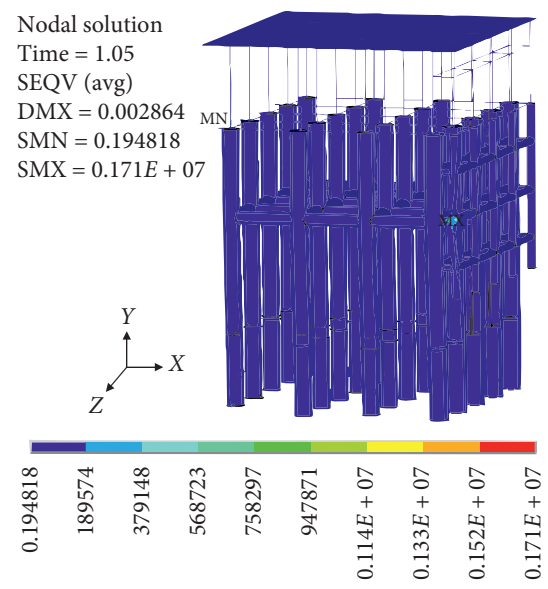

(d)

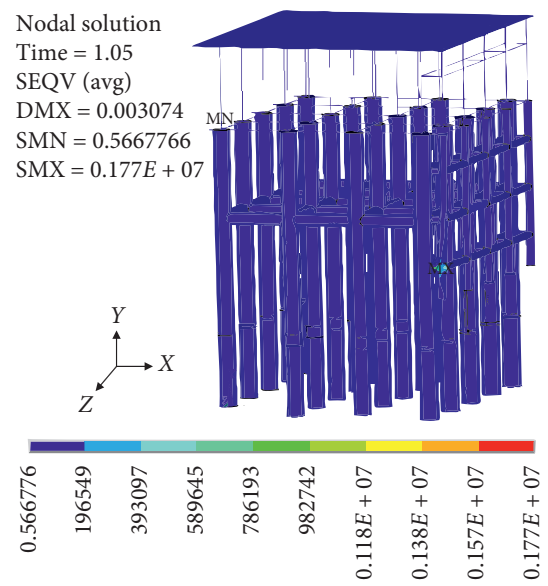

(e)

FIGURE 12: Stress distribution diagram of the structure at maximum response time (unit: $\mathrm{kPa}$ ). (a) Working condition 1 . (b) Working condition 2. (c) Working condition 3. (d) Working condition 4. (e) Working condition 5.

Conversely, the stiffness of the structure is the smallest at the action point of working conditions $3-5$, and the local deformation and energy absorption of the action point are larger.

(3) From the analysis of the displacement-time history curve of the joint shown in Figure 11, it can be seen that the displacement-time history curve is approximately half sinusoidal waveform during the action time of the impact load of 2 seconds, which is consistent with the impact load-time history curve waveform. The displacement value of the observed node increases sharply in the first 1.0 second and decreases in the last 1.0 second. Since $6 \mathrm{~S}$ after the time history curve is the monitoring of the structural vibration after loading, at this time, because of the natural vibration of the structure, the node of the 


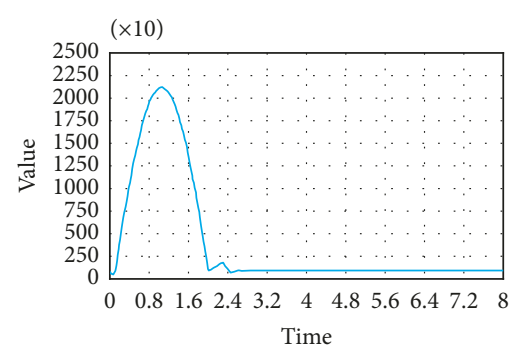

(a)

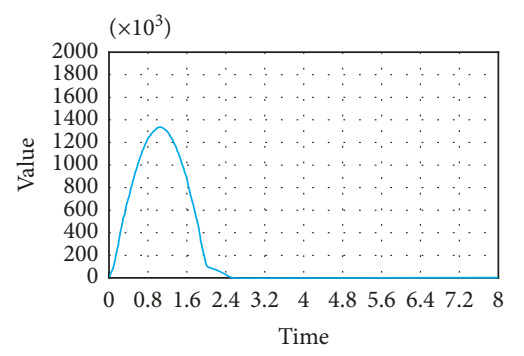

(c)

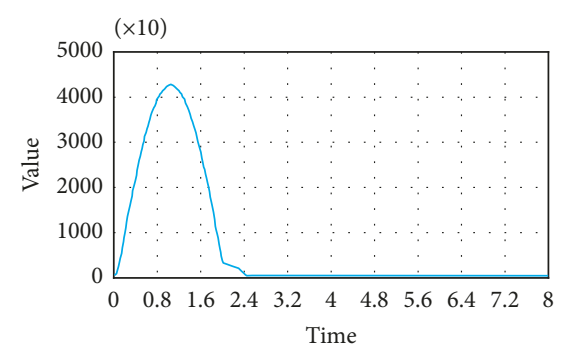

(b)

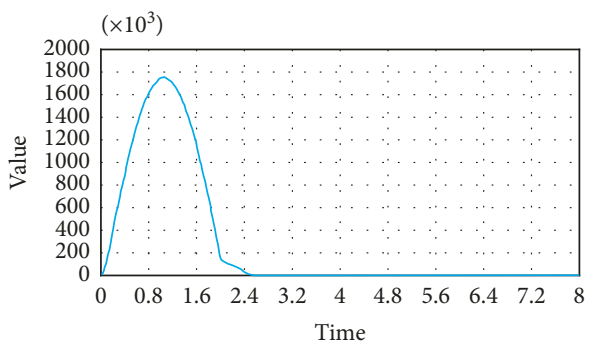

(d)

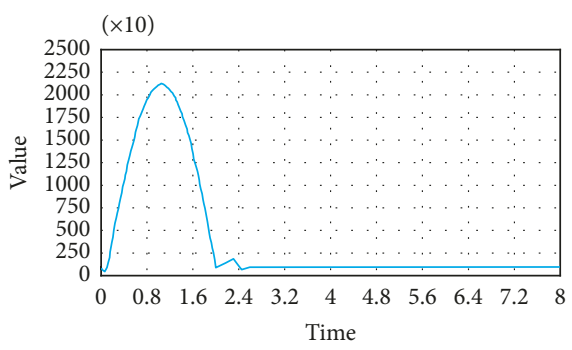

(e)

Figure 13: von Mises stress-time curve of maximum stress node (unit: kPa). (a) Working condition 1. (b) Working condition 2. (c) Working condition 3. (d) Working condition 4. (e) Working condition 5.

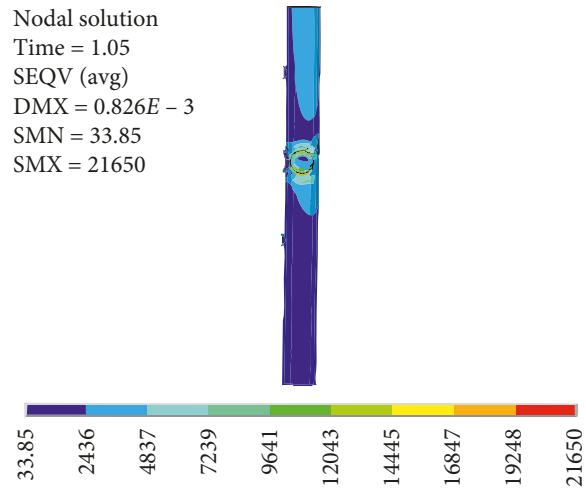

(a)

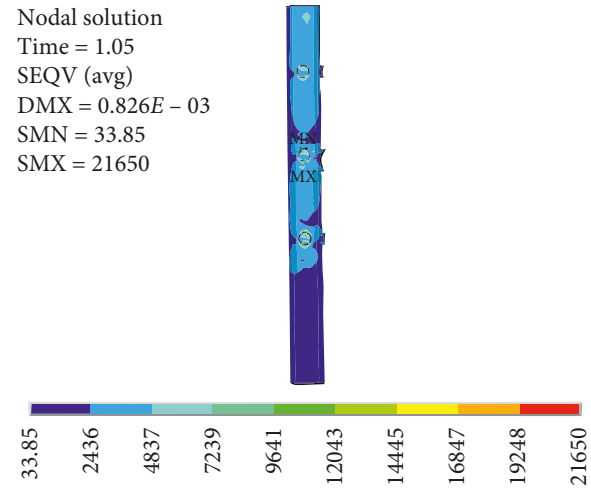

(b)

FIGURE 14: Equivalent stress diagram of Z1 steel casing on the shore side under working condition 1 (unit: kPa). (a) Shore side. (b) River side.

structure has obvious displacement that is opposite to the loading direction at $2.3 \mathrm{~s}$, and the maximum displacement does not exceed $1 / 13$ of the loading direction displacement. Under the condition of the impact dynamic load and the consolidation of the pile bottom, the structure shows positive and negative back-and-forth vibration of the load action, but the vibration in the direction of the load phase is very small and can be neglected.

3.2.2. Stress of the Structure. The peak stress of the pile foundation structure and its location under five working conditions are shown in Table 4. Table 5 lists the stress peak 


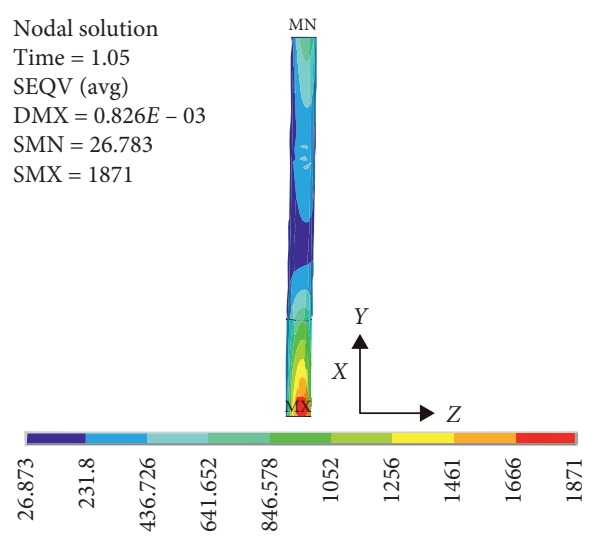

(a)

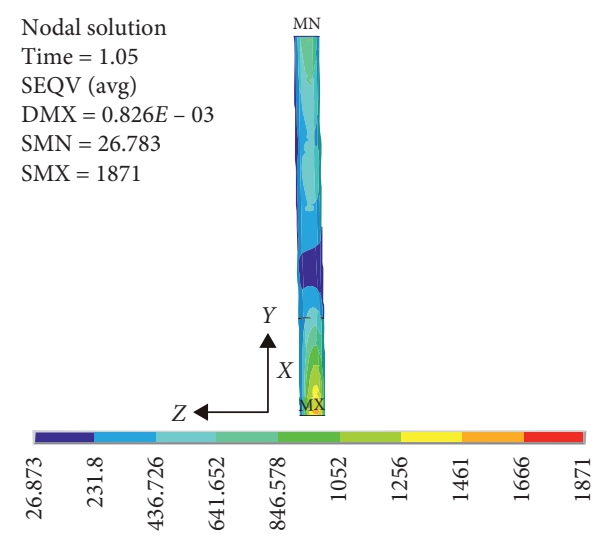

(b)

FIGURE 15: Equivalent stress diagram of Z1 reinforced concrete pile on the shore side under working condition 1 (unit: $\mathrm{kPa}$ ). (a) Shore side. (b) River side.

TABle 3: Maximum lateral displacement and response time of key points of structures.

\begin{tabular}{|c|c|c|c|c|c|c|}
\hline Name & & $\begin{array}{l}\text { Working } \\
\text { condition } 1\end{array}$ & $\begin{array}{c}\text { Working } \\
\text { condition } 2 \\
\end{array}$ & $\begin{array}{c}\text { Working } \\
\text { condition } 3\end{array}$ & $\begin{array}{c}\text { Working } \\
\text { condition } 4\end{array}$ & $\begin{array}{l}\text { Working } \\
\text { condition } 5 \\
\end{array}$ \\
\hline \multirow{2}{*}{$\begin{array}{l}\text { Maximum out-of-river displacement } \\
\text { of top joints of structures }\end{array}$} & $\begin{array}{c}\text { Size } \\
\left(\times 10^{-3} \mathrm{~m}\right)\end{array}$ & 0.910 & 1.577 & 0.713 & 0.591 & 0.440 \\
\hline & $\begin{array}{l}\text { Response } \\
\text { time }(\mathrm{s})\end{array}$ & $1.05 \mathrm{~s}$ & $1.05 \mathrm{~s}$ & $1.05 \mathrm{~s}$ & $1.05 \mathrm{~s}$ & $1.05 \mathrm{~s}$ \\
\hline \multirow{2}{*}{$\begin{array}{l}\text { Maximum river-oriented } \\
\text { displacement of top joints of } \\
\text { structures }\end{array}$} & $\begin{array}{c}\text { Size } \\
\left(\times 10^{-3} \mathrm{~m}\right)\end{array}$ & 0.0528 & 0.0811 & 0.0446 & 0.0395 & 0.0331 \\
\hline & $\begin{array}{l}\text { Response } \\
\text { time }(\mathrm{s})\end{array}$ & $2.3 \mathrm{~s}$ & $2.3 \mathrm{~s}$ & $2.3 \mathrm{~s}$ & $2.3 \mathrm{~s}$ & $2.3 \mathrm{~s}$ \\
\hline \multirow{2}{*}{$\begin{array}{l}\text { Maximum offshore displacement of } \\
\text { impacted joints }\end{array}$} & $\begin{array}{c}\text { Size } \\
\left(\times 10^{-3} \mathrm{~m}\right)\end{array}$ & 0.897 & 1.555 & 2.700 & 2.794 & 2.991 \\
\hline & $\begin{array}{l}\text { Response } \\
\text { time }(\mathrm{s})\end{array}$ & $1.05 \mathrm{~s}$ & $1.05 \mathrm{~s}$ & $1.05 \mathrm{~s}$ & $1.05 \mathrm{~s}$ & $1.05 \mathrm{~s}$ \\
\hline \multirow{2}{*}{$\begin{array}{l}\text { Maximum riverward displacement of } \\
\text { impacted joints }\end{array}$} & $\begin{array}{c}\text { Size } \\
\left(\times 10^{-3} \mathrm{~m}\right)\end{array}$ & 0.0442 & 0.0751 & 0.113 & 0.115 & 0.118 \\
\hline & $\begin{array}{l}\text { Response } \\
\text { time (s) }\end{array}$ & $2.3 \mathrm{~s}$ & $2.3 \mathrm{~s}$ & $2.3 \mathrm{~s}$ & $2.3 \mathrm{~s}$ & $2.3 \mathrm{~s}$ \\
\hline
\end{tabular}

TABLE 4: Maximum von Mises equivalent stress table for the whole structure.

\begin{tabular}{|c|c|c|c|c|c|}
\hline Name & Working condition 1 & Working condition 2 & $\begin{array}{c}\text { Working } \\
\text { condition } 3\end{array}$ & $\begin{array}{c}\text { Working } \\
\text { condition } 4\end{array}$ & $\begin{array}{c}\text { Working } \\
\text { condition } 5\end{array}$ \\
\hline $\begin{array}{l}\text { Maximum stress value } \\
(\mathrm{kPa})\end{array}$ & 21650 & 42580 & $1.66 \times 10^{6}$ & $1.70 \times 10^{6}$ & $1.77 \times 10^{6}$ \\
\hline $\begin{array}{l}\text { Maximum stress } \\
\text { response time (s) }\end{array}$ & 1.05 & 1.05 & 1.05 & 1.05 & 1.05 \\
\hline $\begin{array}{l}\text { Location of maximum } \\
\text { stress occurrence }\end{array}$ & $\begin{array}{l}\text { The lower side of the } \\
\text { connection between the first } \\
\text { row of steel barrels and steel } \\
\text { braces }\end{array}$ & $\begin{array}{l}\text { The lower side of the } \\
\text { connection between the first } \\
\text { row of steel barrels and steel } \\
\text { braces }\end{array}$ & $\begin{array}{l}\text { Impact point of } \\
\text { steel pillar }\end{array}$ & $\begin{array}{l}\text { Impact point of } \\
\text { steel pillar }\end{array}$ & $\begin{array}{l}\text { Impact point of } \\
\text { steel pillar }\end{array}$ \\
\hline
\end{tabular}

values of the main components of the lower structure of the test model under various working conditions. In addition, the stress distribution diagram of the whole structure under different working conditions at the maximum response time is given, and the nodes that produce the maximum stress response are taken as the key points. The stress-time history diagram is also shown.
(1) As can be seen from Table 4 and Figures 12 and 13, the maximum stress response time of the wharf model structure under a low-speed impact load is $1.05 \mathrm{~s}$, and the stress waveform and load remain constant. The peak value is $0.05 \mathrm{~s}$ later than the peak value of the impact load. At the end of impact loading, different degrees of stress vibration 
TABLE 5: von Mises equivalent stress peak table of pile foundation structure.

\begin{tabular}{|c|c|c|c|c|c|c|}
\hline \multirow{2}{*}{\multicolumn{2}{|c|}{ Structural computing components }} & \multicolumn{5}{|c|}{ Computational results } \\
\hline & & $\begin{array}{l}\text { Working } \\
\text { condition } 1\end{array}$ & \multirow{2}{*}{$\begin{array}{c}\text { Working } \\
\text { condition } 2 \\
39168\end{array}$} & \multirow{2}{*}{$\begin{array}{c}\text { Working } \\
\text { condition } 3\end{array}$} & $\begin{array}{l}\text { Working } \\
\text { condition } 4 \\
\end{array}$ & $\begin{array}{l}\text { Working } \\
\text { condition } 5\end{array}$ \\
\hline \multirow[b]{2}{*}{ P1Z4 steel casing $(\mathrm{kPa})$} & River side & 19642 & & & 14079 & 53400 \\
\hline & $\begin{array}{l}\text { Shore } \\
\text { side }\end{array}$ & 3969.2 & 9461.6 & 3944.8 & 4155 & 24936 \\
\hline \multirow{2}{*}{$\begin{array}{l}\mathrm{P} 1 \mathrm{Z} 4 \text { concrete pile foundation } \\
(\mathrm{kPa})\end{array}$} & River side & 1355.3 & 2978.2 & 1420.1 & 1121.3 & 2286.5 \\
\hline & $\begin{array}{l}\text { Shore } \\
\text { side }\end{array}$ & 1823.1 & 3492.9 & 1813.5 & 1446.4 & 1888.4 \\
\hline \multirow[b]{2}{*}{$\mathrm{P} 1 \mathrm{Z} 1$ steel casing $(\mathrm{kPa})$} & River side & 12984 & 29236 & 34110 & 51611 & 1557 \\
\hline & $\begin{array}{l}\text { Shore } \\
\text { side } \\
\end{array}$ & 21650 & 42685 & 24966 & 14556 & 24966 \\
\hline \multirow{2}{*}{$\begin{array}{l}\mathrm{P} 1 \mathrm{Z1} \text { concrete pile foundation } \\
(\mathrm{kPa})\end{array}$} & River side & 1471.1 & 3211.7 & 1557 & 2574.5 & 1911.6 \\
\hline & $\begin{array}{l}\text { Shore } \\
\text { side } \\
\end{array}$ & 1806.2 & 3464.4 & 1911.6 & 2950.8 & 1557 \\
\hline \multirow{2}{*}{$\mathrm{P} 1$ bent steel cross brace $(\mathrm{kPa})$} & $\begin{array}{l}\text { Upper } \\
\text { side }\end{array}$ & 10661 & 20965 & 11750 & 6887 & 11242 \\
\hline & $\begin{array}{l}\text { Under } \\
\text { side }\end{array}$ & 11526 & 23172 & 12485 & 11385 & 13264 \\
\hline \multirow{2}{*}{$\begin{array}{l}\text { P1 bent steel berthing column } \\
(\mathrm{kPa})\end{array}$} & River side & 5698.8 & 27785 & 1657800 & 1706200 & 1768900 \\
\hline & $\begin{array}{l}\text { Shore } \\
\text { side } \\
\end{array}$ & 11819 & 27120 & 60117 & 72759 & 58926 \\
\hline \multirow{2}{*}{$\mathrm{P} 1$ bent steel front brace $(\mathrm{kPa})$} & $\begin{array}{l}\text { Upper } \\
\text { side }\end{array}$ & 7841.6 & 17685 & 11293 & 29258 & 19368 \\
\hline & $\begin{array}{l}\text { Under } \\
\text { side }\end{array}$ & 9385.1 & 20980 & 12358 & 39896 & 24458 \\
\hline
\end{tabular}

P1 is the first framed bend, and $\mathrm{Z} 1$ is the first row of the steel barrel socketed piles from the river side to the bank side.

appeared in various working conditions. In working condition 1 and working condition 2 , the maximum stress appears on the lower side of the joint between the first row of the steel casing and the steel cross bracing, that is, the welding place of the two steel members of the steel casing and the steel cross bracing. The maximum stress in working conditions 3-5 occurs near the impact force acting on the steel docking column. Thus, when the structure is subjected to a horizontal dynamic load, the maximum stress appears in the weakest part of the structure. From the point of view of the equivalent force peak in the whole structure, the stress peak value of the components in working conditions $3-5$ is 102 times larger than that in working conditions 1-2. This is because of the hollow steel tube of the docking column at the loading points of the latter three working conditions; the transverse stiffness is less than the longitudinal stiffness of the steel tube at the junction of the steel transverse brace and the steel casing, and the steel casing is wrapped by a reinforced concrete core.

(2) From Table 5, it can be seen that the peak stress values of the steel casing members under the same working condition are generally larger than those of reinforced concrete pile foundations. This indicates that the steel casing absorbs more impact energy during structural transmission under impact force and the mechanical properties of the reinforced concrete piles are not fully developed. Figures 14 and 15 show that the stress concentration of the steel casing is extensive at the joints of the longitudinal and transverse braces, while the stress distribution of the reinforced concrete pile core in the steel casing is relatively uniform because of the hoop action of the steel sheath. The maximum stress of the pile foundation appears in the embedded section of the foundation because the lateral loads on the superstructure are ultimately borne by the embedded section of the pile foundation, and there are no lower stiffness components in the embedded section of the pile to absorb the energy resulting from the impact load.

\section{Conclusion}

The dynamic response analysis of the first structural section of the second-phase wharf of Chongqing Orchard Port under lateral impact load reveals several phenomena:

(1) The rigidity of the model structure of the rocksocketed cast-in-place pile wharf with steel casing was strengthened by the reinforcement of the longitudinal and transverse braces of reinforced concrete and the frame structure of the steel longitudinal and transverse braces. The integrality is good, but the longitudinal rigidity of the structure needs to be strengthened. The modal frequencies of the structure are concentrated in segments, and the stiffness values of the same group of modes of the model structure are close to each other. This shows that the stiffness 
distribution of the structure is uniform, and the frequency jumps between different frequency bands, which is necessary to avoid the excitation loads near each dense frequency band.

(2) The displacement response of the frame structure to transverse impact dynamic load is consistent for different load action points. It is necessary to avoid the transverse load action in the position at which the local stiffness of the frame structure is larger in order to avoid the back-and-forth vibration caused by excessive displacement of the whole structure.

(3) The stress response-time history of the structure is consistent with the load waveform. At the end of the $2 S$ load, stress vibration occurs. The overall stiffness of the frame structure is better, but the stress concentration occurs in the longitudinal/transverse braces, the steel casing, and their connections. The stress distribution of the reinforced concrete pile core is relatively uniform because of the hoop action of the steel casing, and the stress at the bottom of the embedded section of the foundation is larger. In the design, other longitudinal/transverse braces with higher stiffness should be considered, and new structural forms should be used to reinforce or distribute stress in places connected with steel casing. Steel-concrete cooperative structural forms made of steel casing and reinforced concrete pile cores with improved mechanical properties should be adopted.

(4) This paper reports the dynamic response analysis of the overhead vertical wharf with rock-socketed steel sheath piles. The influence of welding effects, such as the influence of the steel longitudinal/transverse brace and steel sheath on the structural dynamic response, was not considered, and the dynamic coupling response of the single-foundation embedded in the pile foundation was not considered. Further research should be carried out in combination with the theory of steel-concrete structure coupling and pile-foundation coupling.

\section{Data Availability}

The data used to support the findings of this study are available from the corresponding author upon request.

\section{Conflicts of Interest}

The authors declare that they have no conflicts of interest.

\section{Acknowledgments}

The authors would like to acknowledge the financial support from the National Natural Science Foundation of China under contract no. 51579021.

\section{References}

[1] G. M. Yan, "Design and construction of dashi bridge in Japan," Overseas Bridges, vol. 199, no. 4, 1997.
[2] L. A. Montejo, L. A. González-Román, and M. J. Kowalsky, "Seismic performance evaluation of reinforced concrete-filled steel tube pile/column bridge bents," Journal of Earthquake Engineering, vol. 16, no. 3, pp. 401-424, 2012.

[3] C. Z. Wang and D. Y. Feng, "Experimental study on bearing capacity of steel sheath and reinforced concrete structures," Waterway Engineering, no. 1, pp. 167-172, 2019.

[4] J. P. Li, D. Y. Wang, and C. Z. Wang, "Numerical analysis and model validation of horizontal stress mechanism of steel casing and concrete piles," Waterway Engineering, no. 5, pp. 125-131, 2016.

[5] B. G. Mu, X. Ban, and W. M. Gong, "Analysis of horizontal bearing capacity of hybrid pile considering the effect of steel casing," Civil and Environmental Engineering, vol. 33, no. 3, pp. 68-73, 2011.

[6] L. S. Huang and X. Z. Feng, "Construction treatment and calculation analysis of steel casing involved in pile body stress," Structural Engineering, vol. 21, no. 4, pp. 52-55, 2005.

[7] J.-J. Chen, J.-H. Wang, X. Ke, and D.-S. Jen, "Behavior of large-diameter rock-socketed piles under lateral loads," International Journal of Offshore and Polar Engineering, vol. 21, no. 4, pp. 323-329, 2011.

[8] J. G. Liu, C. Z. Wang, and S. Y. Pan, "Study on joint mechanical behavior of large diameter steel casing steel cross support and reinforced concrete pile foundation," Waterway Engineering, no. 9, pp. 132-137, 2013.

[9] C. Z. Wang, J. G. Liu, and X. Y. Shi, "Analysis of mechanical characteristics of overhead vertical wharf with inland river large water difference combined with steel casing and reinforced concrete," Waterway Engineering, no. 6, pp. 115-120, 2012.

[10] J. Eibl, "Design of concrete structures to resist accidental impact," Structural Engineering, Part A, vol. 65A, no. 1, 1987.

[11] J. M. Louw, "RC cantilever columns under lateral impact load: an experimental investigation," in Proceedings of the Second International Conference on Structures under Shock and Impact II, Portsmouth, UK, June 1992.

[12] H. L. Riad and A. Scanlon, "Dynamic response of concrete structures under direct impact," in Proceeding of the Secongd International Conference on Structures under Shock and Impact II, pp. 235-245, Computational Mechanics Publication, Portsmouth, UK, June 1992.

[13] H.-Q. Zhang, X.-P. Sun, Y.-Z. Wang, J.-L. Yin, and C.-Y. Wang, "Dynamic characteristics and simplified numerical methods of an all-vertical-piled wharf in offshore deep water," China Ocean Engineering, vol. 29, no. 5, pp. 705-718, 2015.

[14] Y.-Z. Wang and L.-L. He, "Simplified calculation methods for all-vertical-piled wharf in offshore deep water," China Ocean Engineering, vol. 31, no. 2, pp. 182-191, 2017.

[15] R. L. Boroschek, H. Baesler, and C. Vega, "Experimental evaluation of the dynamic properties of a wharf structure," Engineering Structures, vol. 33, no. 2, pp. 344-356, 2011.

[16] A. Miyamato and M. Beppu, "3-D dynamic analysis and computer graphics application to impact failure simulation for reinforced concrete slabs," in Proceedings of the International Conference on Structures under Shock and Impact, SUSI, pp. 727-741, Computation Mechanics Inc., Thessaloniki, Greece, June 1998.

[17] H. B. Ge and T. Usami, "Strength of concrete-filled thinwalled steel box column:experiment," Journal of Structual Engineering, ASCE, vol. 118, no. 11, pp. 3036-3054, 1992.

[18] T. G. Zhang, Oblique Impact and Rupture of Thin Metal Tubes, Ph.D., University of Cambridge, Cambridge, UK, 1996. 
[19] Q. D. Pu, "Vibration mode analysis of fan shell," in Proceedings of the 90th Anniversary of Shanghai Jiaotong University, Shanghai, China, 1986.

[20] P. Y. Gu and W. P. Wang, "Modal test of large cylindrical wharf structure," in Proceedings of National Conference on Vibration Engineering Applications, pp. 457-461, Beijing, china, 2002.

[21] J. Y. Huang, D. Y. Wang, and X. Y. Shi, "Modal analysis of structural characteristics of inland overhead vertical container terminal," Journal of Chongqing Jiaotong University, no. 3, pp. 463-466, 2008.

[22] C. T. Song and Q. X. Liu, "Modal analysis of structural performance of overhead slope of vehicle lower river wharf," Jilin Water Resources, vol. 340, no. 9, pp. 18-21, 2010.

[23] W. J. Xu, G. G. Lei, and Z. Y. Li, "Cause analysis and treatment measures of sloshing of high-pile beam-slab wharf," Waterway Engineering, vol. 450, no. 2, pp. 58-61, 2011.

[24] S. L. Zhou, F. Q. Wu, Q. Wang, and F. H. Li, "Modal analysis of overhead pier bulk cargo wharf in three Gorges reservoir area," Port Engineering Technology, vol. 194, no. 3, pp. 25-28, 2010.

[25] X. J. Shang, F. Qiu, and H. F. Zhao, ANSYS Advanced Finite Element Analysis Method and Example Application, China Water Resources and Hydropower Publishing House, Beijing, China, 2008.

[26] S. J. Prichard and S. H. Perry, "The impact behavior of sleeved concrete cylinders," Structural Engineering, vol. 78, no. 17, pp. 23-27, 2000. 


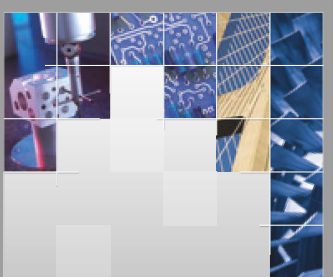

\section{Enfincering}
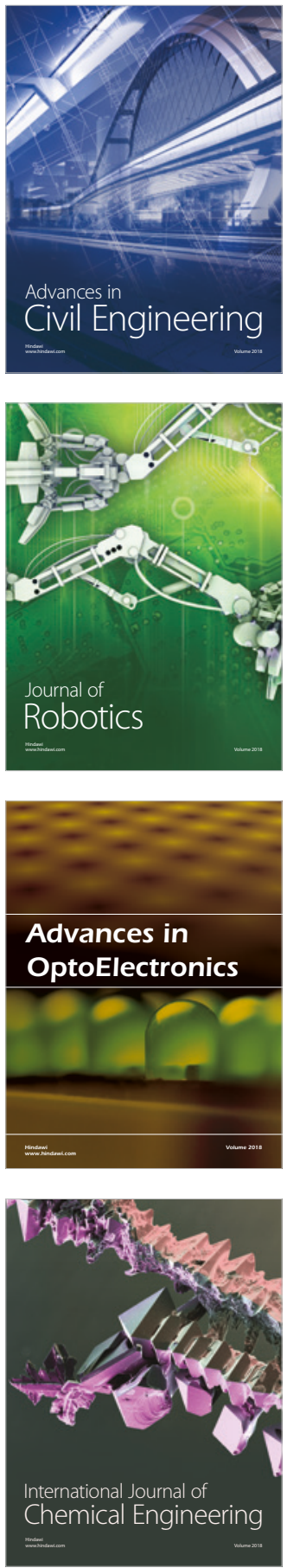

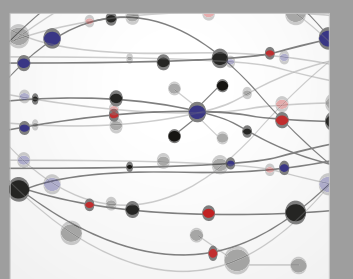

\section{Rotating \\ Machinery}

The Scientific World Journal

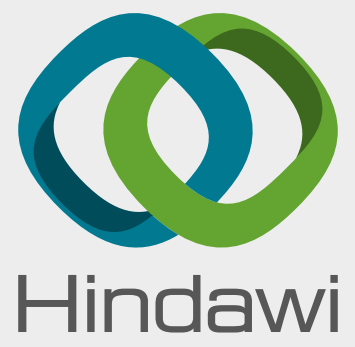

Submit your manuscripts at

www.hindawi.com
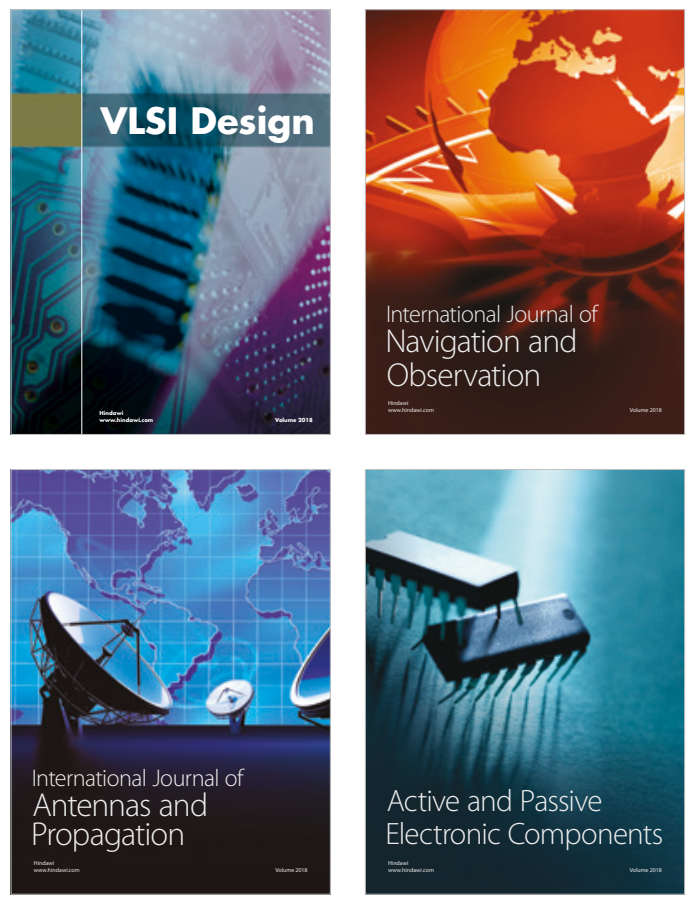
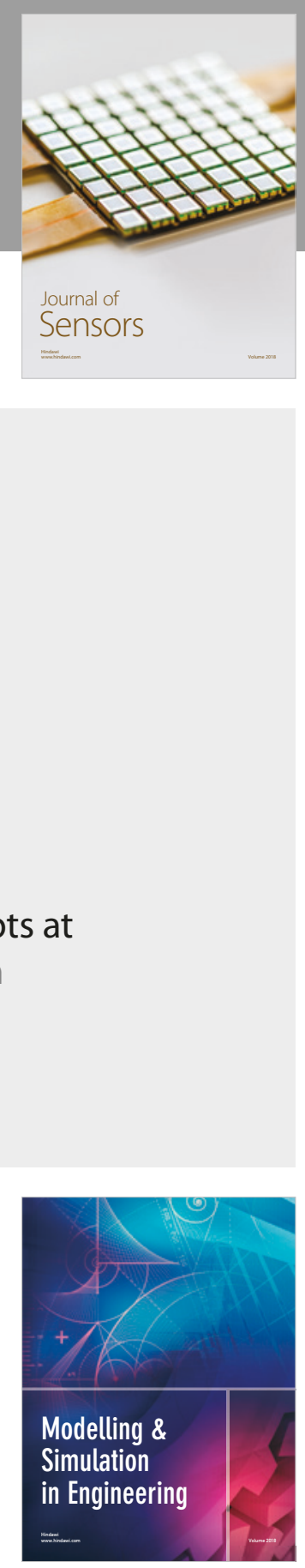

\section{Advances \\ Multimedia}
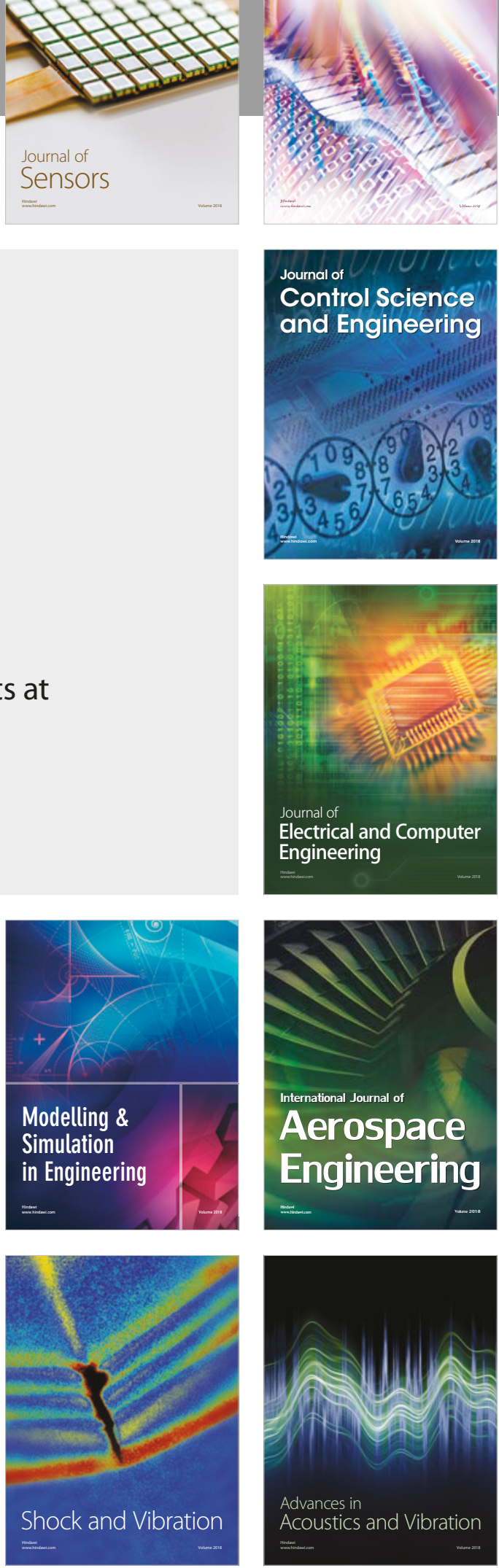